\title{
CONCEPT OF VYADHIKSHAMATVA IN AYRVEDA
}

\author{
VD. Neha Madhukar Pawar 1, VD. Archana Kulkarni ${ }^{* 2}{ }^{\square}$ \\ ${ }^{1}$ P.G student of Roga nidan avum vikriti vigyana, BSDTs Ayurveda Mahavidyalaya Wagholi, Pune, \\ Maharashtra, India \\ ${ }^{* 2}$ Guide and HOD, BSDTs Ayurveda Mahavidyalaya Wagholi, Pune, Maharashtra, India
}

DOI: https://doi.org/10.29121/granthaalayah.v8.i8.2020.1064

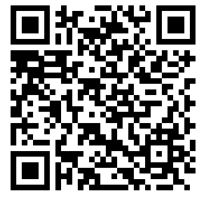

Article Type: Research Article

Article Citation: VD. Neha

Madhukar Pawar, and VD. Archana

Kulkarni. (2020). CONCEPT OF

VYADHIKSHAMATVA IN AYRVEDA.

International Journal of Research -

GRANTHAALAYAH, 8(8), 239-243.

https://doi.org/10.29121/granthaa

layah.v8.i8.2020.1064

Received Date: 10 July 2020

Accepted Date: 30 August 2020

Keywords:

Vyadhikshamatva

Ayrveda

Concept

\section{ABSTRACT}

For prevention of diseases, Ayurveda had advocated the adherence to concepts like dina charya, ritu charya, sadvritta, Na vega dharan etc. these measures are useful in preventing the lifestyle related diseases but for preventing the Aupsargik rogas (communicable diseases), Janapada dhwansa rogas (epidemic diseases), Krumij Roga (Infectious diseases), Asatmyaj roga (allergic disorders), the concept of Vyadhikshamtva (Immunity) is propagated by the Ayurvedic science [1]. According to the concept of Ojas or Vyadhikshamatva or Bala (immunity), the body"s resistance is of tremendous importance in the daily welfare of living beings not only for disease prevention but also for rapid recovery after disease affliction. [2] Ayurveda propounds that prevention is an equally important aspect of disease management as cure and thus, strengthening the immune system, is a natural way to help the body fight against the disease-causing pathogens. Acharyas promoted the use of Rasayana (Rejuvenation) to enhance ojas and vyadhikshamatva (immunity).

This article is an effort to present Ayurvedic concepts of Vyadhishamatva.

\section{INTRODUCTION}

The healthy and joyful long life is the main priority of Ayurveda. Ayurveda explained the concepts related to health and diseases in details, also the knowledge of etiology, symptomology, therapeutics, numerous methods to sustain healthy status and causes behind falling sick. [3] The main purpose and objectives of Ayurveda is the preservation of health in healthy individual and eradication of diseases which are curable.

The concept of Vyadhiksamatva (immunity) is of tremendous importance in the daily wellness of human beings; for prevention and recovery from diseases. When etiological factors come in contact with the body they try to produce disease. At the same time the body tries to resist the disease. This power of the body, which prevents the development of diseases or resists a developed disease, is called Immunity. Vyadhikshamatva in Ayurveda is not merely immunity against a specific infectious agent or disease such as typhoid, measles or rubella for which modern medicine provides "immunizations". Rather, Vyadhikshamatva implies a resistance against the loss of the integrity, proportion, and interrelationship amongst the individual's doshas (bioenergies) and dhatus (tissues). Resistance to disease or immunity against disease is of two kinds i.e. the one which attenuate the manifested diseases and other variety prevents the manifestation of diseases 
Various factors which contribute towards vyadhikshamatva are normal doshas, equilibrium state of dhatus normal agni, patency of srotas etc. During certain conditions or due to certain factors even unwholesome (ahitakara) dietary practices do not produce disease immediately. All unwholesome (ahitekar) food articles are not equally harmful, all doshas are not equally powerful; all persons are not equally capable of resisting diseases [4] Vyadhikshamatva helps in to achieve the aim of Ayurveda i.e.

\section{स्वास्थस्य स्वास्थ्य रक्षणम्। आतुरस्य विकार प्रशमनम् च।। [5]}

Ayurvedic literature from ancient texts to usnderstand role of Vyadhikshamatva as per Ayurveda concept which may be helpful in this battle for survival of human beings.

\section{MATERIAL AND METHOD}

The materials were collected from the classical Ayurvedic literatures, magazines and research journals.

\section{NIRUKTI}

- It is made of two words i.e. vyadhi and kshamatva.

- व्याधि - व्याध् तदने। i.e. it means the condition which gives pida to adhisthan or body.

- क्षमत्व - क्षमुस् सहने। It means Shakti or samarthya.

\section{DEFINITION}

\section{व्याधिक्षमत्वं व्याधिबलविरोधित्वं व्याध्युत्पाद प्रतिबन्धकत्वमिति यावत्। [6]}

Vyadhikshamatwa is illustrated as the power of resistance capable enough to check the progress occurrence or recurrence of disease.

\subsection{SYNONYMS}

Synonyms for Vyadhikshamatva which appears in Ayurvedic scriptures are:

Sleshma, Bala and Ojas. [7]

\subsection{SLESHMA}

The Kapha is one of the Tridisha which retains the properties such as Singdha , Sita ,Guru , Manda , Slaksna , Mrstna , Sthira. [8] The normal phase of sleshma is called as Bala and Oja and abnormal phase is called as Mala and Papma [9]

Kapha in normal state function as that of Ojas. Kapha in normal state offers compactness(solidity), stability(constancy), heaviness, virility, immunity, resistance, courage and gracelessness. [10]

\subsection{BALA}

तत्र बलेन स्थिरोपचितमांसता सर्वचेष्टास्वप्रतिघातः सर्ववर्णप्रसादो बाहयानाम् अभ्यन्तरानाम् च करनंआत्मकम् कार्य प्रतिपति भवन्ति। [11]

Means Bala imparts firm integrity to the muscles, improves the voice and complexion, and helps the person to perform his natural functions 
Three types of bala (Vyadhiksamatva or immunity) are described.

त्रिविधं बलमिति [12]

1) Sahaja

2) Kalaja

3) Yuktikrita

\subsection{SAHAJA BALA}

\section{सहजं वत् शरीरसत्वयोः।}

The constitutional strength present since birth It depends on the healthiness of shukra (sperms) and artava (ovum). According to Ayurvedic concept of Genetics, if two parents" genetic makeup is healthy, then children are similar healthy If parents is susceptible to certain diseases, those diseases may be carried over into the next generation [13] This concept indicates congenital abnormalities which occur due to abnormal changes at genes or chromosomal levels.

\subsection{KALAJA BALA}

$$
\text { कालकृतं ऋतुविभागजं वयकृतं च। }
$$

Temporal strength is the one which is based on division of seasons and age of the person. In Adana kala (late winter, spring and summers) Bala of individual will be less and in Visarga kala (rainy seasons, autumn and winter) it will be more. Bala will be Alpa (minimum) in child and old age, Uttama (maximum) in young age.

\subsection{YUKTIKRITA BALA}

$$
\text { युक्तिकृतं पुनस्तद्याहारचेष्टा योगजं। }
$$

Acquired strength is the one which is achieved by the combination of diet and physical activities.

\subsection{OJAS}

The essence of saptadhatus is called Oja and it is the seat for strength, hence called bala situated in the heart It is viscous, unctuous, greasy, Somatmaka (preponderant in watery principal), clear (transparent) and slight reddish yellow in color. its loss (destruction, absence) may lead to death and its presence in the body (and life) sure to survive. 13

\section{Classification of OAJAS}

According to chakrapani Oajas is of two types [14]

Para Oajas: Para Oajas is prime Oajas, where Prana the life resides. It is 8 drops in quantity, present in heart, even a part of destruction of Para Oajas leads to death. It is white and Yellowish red in colour.

Apara Oajas: Apara Oajas is half Anjali in quantity,it is less important compared to Para oajas

\section{Ojakshaya (decrease or loss of 0jas)}

Ojas undergoes decrease by anger, hunger, worry, grief and exertion. With such decrease, the person becomes fretful, debilitated, worries much again, feels discomfort in the sense organ, develop bad complexion, bad mention and dryness of skin. [15] 
According to Sushruta there are three stages of abnormal ity of Oajas are [16]

Oajovisransa: symptoms of Oajovisransa are looseness of joints, body ache, and displacement of Doshas from their seat, tiredness and impairement in performance of action.

Oajovyapada: symptoms of Oajovyapada are heaviness in the body, stiffness in joints, depression, discolouration, body ache, drowsiness, excess sleep and non-pitting ede- ma.

Oajokshaya: symptoms of Oajokshaya are unconscious- ness, depletion of flesh i.e. wasting, semiconsciousness, coma and death.

Vyadhikshamatva and give brief explaination in two divisions.

1) Vyadhi-balavirodhitvam: It is the capacity to put away or resist the power (severity) of the diseases i.e. power to resist the development of disease.

2) Vyadhi-utpadakapratibandhakatva: The counterattacking strength of the body to inhibit the occurrence and re-occurrence of the disease.

\section{FACTORS AFFECTING VYADHIKSHAMATVA}

There are around nine types of factors accountable for reducing the immunity. -Ashtaninditiya Purush.

\section{अतिदीर्घश्च अतिह्नस्वश्च अतिलोमाच अलोम च, अतिकृष्णश्च, अतिगौरवश्च, अतिस्थूलश्च, अतिकृशश्च [17]}

Following are the main factors affecting vyadhikshamtva as described by Acharya Charak: -[18]

Desha, Kala, Samyoga, Virya, Pramana, Oja, Bala, Jatakarma, Lehana karma, Suvarna karma, Dhoopana karma, Niyamita vyayama.

\section{CONCLUSION}

The concept of Vyadhikshmatva is very well documented in Ayurvedic literature.Vyadhikshamatva which is synonyms to swastha, bala and ojas is matter ans substance in present world where every day new short of diseases are evolving. Different persons have different vyadhikshamatva which depends upon oja, bala, season, diet and regimen, anupana, rasa, jaatkarma etc. One should wisely adopt these into his lifestyle so as to make his body and mind strong enough to deal with all the physical and mental stresses of modern era.

\section{SOURCES OF FUNDING}

This research received no specific grant from any funding agency in the public, commercial, or not-for-profit sectors.

\section{CONFLICT OF INTEREST}

The author have declared that no competing interests exist.

\section{ACKNOWLEDGMENT}

None.

\section{REFERENCES}

[1] Subhash D. Waghe* Sanjay P. Deshmukh Critical analysis of Ayurveda Vyadhikshamatva concept w.s.r. to modern immunity April- June 2019 | Vol. 07th | Issue:2nd

[2] karam Singh Bhavna Vermathe concept of vyadhikshamatva (immunity) in ayurveda- Ayurpharm Int J Ayur Alli Sci., Vol.1, No.5 (2012) Pages 99 - 108 
[3] Sharma PV,Charaka. Charaka Samhita, Part 1.. Sutrasthana, Chapter 1 Verse42 Varanasi Chaukhamba Surbharati Prakashan [ 2011];4

[4] Tripathi B, editor(1st) Charaka-Samhita of Agnivesa, SootraSthana Chapter 28, Verse7 Varanasi Chaukhamba Surbharati Prakashan (2008);549-50

[5] TripathiB, editor(1st) Charaka-Samhita of Agnivesa, SootraSthana Chapter 30, Verse 26 VaranasiChaukhambaSurbharatiPrakashan(2008);565

[6] Dr.subhash ranade, dr. Aanad kalaskar Rog-Nidan Part 1 Chapter - 2 Vyadhi Nidan Profishunt publiction house Jan $2017 ; 166$

[7] karam Singh Bhavna Verma the concept of vyadhikshamatva (immunity) in ayurveda - Ayurpharm Int J Ayur Alli Sci., Vol.1, No.5 (2012) Pages 99 - 108

[8] Upadhyaya Y: Editor, Astangahrdaya of Vagbhata,: Sutrasthana, chapter 1, Verse 8-9 Varanasi: Chaukhambha Prakashan, Ed., 2007; 3

[9] TripathiB, editor(1st) Charaka-Samhita of Agnivesh, SootraSthana Chapter 28, Verse7 VaranasiChaukhambaSurbharatiPrakashan( 2008);365

[10] TripathiB,editor(1st)Charaka-Samhita of Agnivesa ,SootraSthana Chapter 17, Verse 117 VaranasiChaukhambaSurbharatiPrakashan( 2008);365

[11] ShastriK.Susrutasamhita of Maharsi - Susruta edited with Ayurveda-Tattva-SandipikaSootraSthana;Chapter 15,verse 25.Varanasi The Kashi Sanskrit Series 156,2011;79

[12] TripathiB,editor(1st)Charaka-Samhita of Agnivesa ,SootraSthana Chapter 11, Verse 36 VaranasiChaukhambaSurbharatiPrakashan( 2008);240

[13] Upadhyaya Y: Editor, Astangahrdaya of Vagbhata,: Sutrasthana, chapter 11, Verse 37-38 Varanasi: Chaukhambha Prakashan, Ed., 2007; 54:

[14] Dr. Brahmanad Tripathi and Dr.Ganga Sahay Pandey, charak ssamhita with charak chandrika Hindi commentary, Sutrasthana, chapter 12, Verse 75 Varanasi: Chaukhambha Prakashan, Ed., 2007; 353

[15] Upadhyaya Y: Editor, Astangahrdaya of Vagbhata,: Sutrasthana, chapter 11, Verse 39-40 Varanasi: Chaukhambha Prakashan, Ed., 2007; 54

[16] ShastriK.Susrutasamhita of Maharsi - Susruta edited with Ayurveda-Tattva-SandipikaSootraSthana;Chapter 15,verse 28-29.Varanasi The Kashi Sanskrit Series 156,2011;80.

[17] TripathiB,editor(1st)Charaka-Samhita of Agnivesa ,SootraSthana Chapter 21, Verse 3 VaranasiChaukhambaSurbharatiPrakashan( 2008);398

[18] TripathiB,editor(1st)Charaka-Samhita of Agnivesa ,SootraSthana $\quad$ Chapter $28, \quad$ Verse 7 VaranasiChaukhambaSurbharatiPrakashan( 2008);547 